\title{
PERIPARTUM CONCENTRATIONS OF ESTRADIOL AND PROGESTERONE IN BLOOD OF PRIMIPAROUS BUFFALOES AS INDICATOR OF PROSPECTIVE POTENCY OF MAMMARY GLAND
}

\author{
G. Ashour ${ }^{1}$, Hoda Z. Hassan ${ }^{2}$, Samah M. Abdel-Rahman², A.M. \\ Hassanein $^{3}$ and M.M. Shafie ${ }^{1}$
}

1- Department of Animal Production, Faculty of Agriculture, University of Cairo, 12613, Giza, Egypt, 2- Animal Production Research Institute, Agricultural Research Center, Ministry of Agriculture, Egypt, 3- Department of Animal Production, Faculty of Agriculture, University of Suez, Canal, Ismailia, Egypt

\section{SUMMARY}

Levels of estradiol (E2) and progesterone (P4) in the peripheral blood of nine Egyptian primiparous buffaloes were assessed in peripartum short period. The animals were divided into three equal groups according to their lactation period length (LP) being, G1 ( $\geq 9$ months), G2 ( $\leq 7$ months) and G3 (non-lactating group). The results of $G 1$, showed increased concentration of E2 continued till it reached its zenith 2 days prior to calving. The rate of increasing E2 level in that time was greater by $110.3 \%$ in $G 1$ than that in G2. After calving, E2 concentration decreased till the $5^{\text {th }}$ day then increased at the $7^{\text {th }}$ day in $G 2$, while, in G1 there was an increase at the days 2 and 7 with a drop on the $5^{\text {th }}$ day. Concentration of E2 was considerably lower $(21.95 \pm 15.01 \mathrm{pg} / \mathrm{ml})$ in $\mathrm{G} 3$ two days before calving in comparison with that of G1 $(200.39 \pm 15.01 \mathrm{pg} / \mathrm{ml})$ and $G 2(95.30 \pm 15.01 \mathrm{pg} / \mathrm{ml})$. NO detectable differences were observed in concentration of P4 among the studied groups, particularly during the precalving period. Lactation period was longer in G1 than that in G2 (285 vs. 156 days), however, the daily milk yield showed the opposite trend. It was slightly greater in $G 2$ than that in G1 (6.4 vs. $6.0 \mathrm{~kg})$.

It is concluded that, peripartum pattern of change in the concentration of E2 may have a good indication for the prospective potency of lactation performance of primiparous buffaloes. The depression in the E2 concentration in the precalving period seems to have a negative effect on postpartum mammary gland activity.

Keywords: Estradiol, progesterone, primiparous buffaloes, milk production

\section{INTRODUCTION}

The endocrine system, perhaps rather than any other physiological system plays a central role in all aspects of mammary gland development (Akers, 2006). The level of reproductive hormones, including; estrogen (E2), progesterone (P4), placental lactogen (PL), prolactin (PRL) and oxytocin (change with the reproductive state) all have a direct action on mammary gland development (Neville et al., 2002). Estrogen alone stimulates mammary ducts proliferation, while normal lobule-alveolar 
development requires synergistic effects of both E2 and P4 (Neville et al., 2001 \& 2002 and Divakar et al., 2008). During the following gestation time, concentration of E2 either remains high or continues to increase and PRL is markedly elevated in blood, while blood flow rate of mammary gland increases. Prepartum extent of transfer of hormones to accumulating secretions in cows is unknown. Moreover, their presence in alveolar-lumina during precalving and lactation periods may have important effects on onset of lactation (Keller et al., 1977).

Recently, more attention has been focused on dairy buffalo because there are many obstacles, severely, affecting its reproductive and lactational performance. Abruptly cessation of milking after calving represents one of those obstacles that affect economic importance of buffalo raising. Ilieva and Peeva (2007) found that the highest percentage of culled buffalo cows was recorded after their first lactation. Meanwhile, Afzal et al. (2007) reported that in order to develop productivity of dairy buffalo it is necessary to develop understanding the factors affecting its milk production. Omar et al. (1994) stated that in Egyptian dairy buffalo herds, some buffaloes calved and failed to lactate or stopped milking after a very short time. Also, it was found according to the farmal records that about $44.4 \%$ of primiparous buffaloes in EL-Nattaf farm were non-lactating after calving.

This study aimed to assess the levels of estradiol and progesterone hormones during precalving and postcalving short periods, in relation to prospective lactation potency of Egyptian primiparous buffaloes.

\section{MATERIALS AND METHODS}

This work was carried out at El-Nattaf El-Kadeem farm (Kafr El-Sheik governorate which located in the northern part of the Nile Delta. This farm belonging to Animal Production Research Institute (APRI), Agricultural Research Center, Ministry of Agriculture and Land Reclamation, Dokki, Giza, Egypt. This study was lasted for 20 months from the beginning of September, 2006 till the end of April, 2008.

\section{Experimental animals:}

Nine primiparous buffaloes were assigned at their late pregnancy ( 2 months before calving) and were closely monitored specially at the days near to the expected day of calving. The animals calved during the period from November, 2006 till July, 2007 after gestation period (lasted 307.8 days on average). The average of age at first calving (AFC) for all heifers was 33.88 months and average of body weight (BW) at calving was $359.17 \mathrm{~kg}$ for the lactating buffalo (LB) groups (G1 and G2), but the non lactating buffalo (NLB) group (G3) was the lowest and ranged between 300 to 312 with an average of $307.33 \mathrm{~kg}$. In addition, the average birth weight of born calves from G1 and G2 groups was $30.5 \mathrm{~kg}$, while that in G3 was $16.67 \mathrm{~kg}$ and all calves in G3 were died after calving by 3 days. These buffalo heifers were housed in shaded open yards. The experimental animals were fed according to the recommendations of APRI. The concentrate ration included; $9.65 \%$ moisture, $7.12 \%$ ash, $16.15 \%$ protein, $2.28 \%$ fat and $11.17 \%$ fiber. Rice straw was available to each buffalo ad libtuim. The nutrient requirements were adjusted according to BW, pregnancy status, and subsequent milk production of each buffalo. After calving, these buffaloes were hand milked for one week and then machine milked twice daily at 5:00 h and 17:00 h. 


\section{Experimental design:}

The experiment lasted till the buffaloes were dried and stopped in milking, then buffaloes were divided into three equal groups according to their lactation period length into G1 (that lactate for $\geq 9$ months), G2 (that lactate for $\leq 7$ months) and G3 (that failed to lactate after calving). Averages of total milk yield (TMY) and length of lactation period (LP) were determined and recorded. Whereas, the average of daily milk yield (DMY) was calculated. The time of recording milk yield proceded the time of blood sampling on the days of blood collection.

Blood samples $(10 \mathrm{ml})$ were obtained from each animal at 7, 5, and, 2 days precalving, on day of calving ( 0 day) and at 2, 5, and 7 days postcalving. Blood samples were collected from the Jugular vein in heparinized tubes at 9.0 am before feeding and watering. Samples were centrifuged at 3000 r.p.m for 20 minutes to separate clear blood plasma, then stored at $\left(-20^{\circ} \mathrm{C}\right)$ until the hormonal assay using the radioimmunoassay (RIA) technique was executed. The assays were executed at the hormonal analysis unit, Faculty of Agriculture Research Park, Cairo University, Egypt.

\section{Estradiol determination:}

A single antibody RIA technique was used to quantify plasma estradiol (E2) using Coat-A-Count kit supplied by Siemens ${ }^{\circledR}$ Medical Solutions Diagnostics, Los Angeles, CA 90045-6900, USA. The used antiserum is highly specific for estradiol with 5.34 intra-assay precision and 6.4 inter-assay precision. The analytical sensitivity is $8 \mathrm{pg} / \mathrm{ml}$.

\section{Progesterone determination:}

A single antibody RIA technique was used to assay plasma progesterone (P4) using Immunotech kit, supplied by A Beckman Coulter Company, Mareseille, France. The used antibody has extremely low cross reaction against other naturally occurring steroids. The intra-assay is $\geq 5.8 \%$ and the inter-assay is $\geq 9.0 \%$. The analytical sensitivity is $0.05 \mathrm{ng} / \mathrm{ml}$.

\section{Statistical analysis:}

Data were analyzed for blood plasma hormones using Repeated Model procedure (SAS, 1999). Significance among means was tested according to Duncan (1995). The model was as follow:

Where:

$$
\mathrm{Y}_{\mathrm{ijk}}=\mu+\mathrm{TRT}_{\mathrm{i}}+\mathrm{T}_{\mathrm{j}}+\mathrm{TRT}_{\mathrm{i}}^{*} \mathrm{~T}_{\mathrm{j}}+\mathrm{e}_{\mathrm{ijk}}
$$

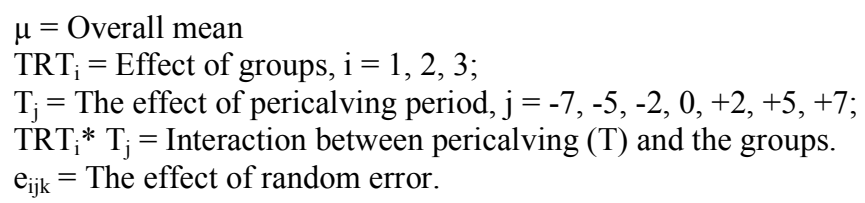

\section{RESULTS AND DISCUSSION}

\section{Estradiol:}

A successful lactation in the dairy cow requires the mammary gland to produce a large number of potential milk secreting cells during pregnancy. These cells subsequently must differentiate during the periparturient period such that the mammary epithelium develops the biochemical and cytological machinery to synthesize and secrete milk. Both mammary growth and initiation of milk synthesis 
are intimately dependent upon complex interactions among hypophyseal, adrenal, ovarian, and placental hormones (Tucker, 1979; Cowie et al., 1980; Delouis et al., 1980; Elias, 1980.; Topper and Freeman, 1980.; and Tucker, 1981).

In the present study, Table (1) and Fig. (1) revealed that the concentrations of estradiol (E2) in G1 and G2 were increased from 7 days precalving and continued to increase till it reached its maximum at 2 days precalving. These maximum concentrations were 200 and $95 \mathrm{pg} / \mathrm{ml}$ in $\mathrm{G} 1$ and G2, respectively. The concentrations declined precipitously on the day of calving, in the two groups, and continued decreasing, on average, to reach the minimum value the fifth day postcalving followed by a considerable increase on the $7^{\text {th }}$ day postcalving. This enormous rise in the concentration of E2 before calving in G1 enhances lactation performance to longer duration and greater total milk yield as recorded in Table (4). Smith et al. (1973) found that the first major change in serum steriods hormones was a 10-fold increase in estrogens during the month before parturition, to a peak at about 2 days before parturition. In this respect, previous studies (Convey, 1974 and Tucker, 1981) also confirmed that the E2 concentration continued increasing within 2 weeks prior calving and reached its zenith 2 days before calving. Erb (1976) clarified the role of E2 in milk secretion and stated that E2 continues to increase until day of calving and may stimulate pituitary release of PRL and enhance rate of milk secretion or perhaps synergize mechanisms required for onset of normal lactation, such as functions of corticoids, growth hormone and other factors in blood plasma. Smith et al. (1973) found that glucocorticiods peak at parturition and return to basal values within $12 \mathrm{hrs}$. and remained near that basal levels for 9 days postpartum. The present results are slightly different from those reported by Henrichs et al. (1972), Chew et al. (1977), Erb et al. (1981) and Kaker et al. (1984) who stated that the peak of E2 level in cattle breeds is on the day of calving not before calving by 2 days, however they stated that the values decline thereafter. It is clear in Table (1) and Fig. (1) that G3 during precalving period had low levels of E2 concentration, especially at 2 days precalving. According to the previous studies (Turner and Bagnara, 1971; Convey, 1974; Tucker, 1981 and Tucker, 2000), it could be deduced that the lower levels of E2 during the precalving period may make these heifers loss the role of E2 in; increasing the enzymatic activity in the secretory cells to be ready to the onset of lactation. E2 acted in at least two ways to initiate lactation: 1) in several species including cattle, it caused release of PRL (which is critically important for initiation of lactation in the periparturient period) from the anterior pituitary gland into blood, 2 ) increasing the number of PRL receptors in mammary cells, which is another lactogenic event (Tucker, 2000). Figure (2) shows that the cocentration of E2 in LB (G1 and G3) was higher than that in NLB (G3) during the different pericalving periods, particulary during the different precalving periods by about $91.6 \%$.

\section{Progesterone:}

Progesterone (P4) concentrations during pericalving stages are shown in Table (2) and Figure (3). At 7 days precalving, the P4 level (ng/ml) in G1 was markedly lower (1.84) than that in G2 (3.14) and that in G3 (3.07). This lowest level in G1 may help in preparation of the mammary gland for lactation. It is clear that G2 showed the highest values of P4 at 7 and 5 days prior calving compared with those in G3 and particularly in G1. From 7 to 2 days before calving, P4 level decreased progressively in $\mathrm{G} 2$ whereas it was dropped dramatically in G3. In contrast, these changes in G1 
were slight to fulfill maintenance of lactation potency (Figure 3). Therefore, it could be suggested that the sharp changes in pre-calving P4 level in both G2 and G3, particularly in G3, may be responsible for the low lactation potency in these groups. From 5 to 2 days before parturition, P4 level slightly increased (9\%) in G1. On the other hand, it was greatly decreased in both G2 (43\%) and G3 (64\%). During the last 2 days of pregnancy, just prior calving, all heifers decreased their P4 level at calving time. This reduction coincides with the last phase of lactogensis.

Table 1. Estradiol concentrations $(\mathrm{pg} / \mathrm{ml})$ in nine Egyptian primiparous buffaloes from 7 days before to 7 days after calving (LSM \pm S.E.)

\begin{tabular}{|c|c|c|c|c|c|c|c|c|}
\hline \multirow{2}{*}{ Group } & \multicolumn{3}{|c|}{ Precalving } & \multirow{2}{*}{$\begin{array}{c}\text { Calving } \\
0\end{array}$} & \multicolumn{3}{|c|}{ Postcalving } & \multirow{2}{*}{ Average } \\
\hline & -7 & -5 & -2 & & +2 & +5 & +7 & \\
\hline G1 & $\begin{array}{c}95.0 \\
\pm 15.0\end{array}$ & $\begin{array}{l}134.23 \\
\pm 15.01\end{array}$ & $\begin{array}{l}200.39 \\
\pm 15.01\end{array}$ & $\begin{array}{c}31.80 \\
\pm 15.01\end{array}$ & $\begin{array}{c}37.55 \\
\pm 15.01\end{array}$ & $\begin{array}{c}17.40 \\
\pm 22.93\end{array}$ & $\begin{array}{c}35.36 \\
\pm 15.01\end{array}$ & $81.90^{\mathrm{a}}$ \\
\hline G2 & $\begin{array}{c}85.7 \\
\pm 31.0\end{array}$ & $\begin{array}{c}82.32 \\
\pm 15.01\end{array}$ & $\begin{array}{c}95.30 \\
\pm 15.01\end{array}$ & $\begin{array}{c}39.43 \\
\pm 30.95\end{array}$ & $\begin{array}{c}19.04 \\
\pm 15.01 \\
\end{array}$ & $\begin{array}{c}19.04 \\
\pm 15.01\end{array}$ & $\begin{array}{c}32.65 \\
\pm 15.01 \\
\end{array}$ & $53.96^{\mathrm{b}}$ \\
\hline Average & 90.4 & 108.27 & 147.84 & 35.61 & 28.29 & 18.22 & 34.01 & 66.08 \\
\hline G3 & $\begin{array}{l}110.1 \\
\pm 21.2 \\
\end{array}$ & $\begin{array}{c}48.82 \\
\pm 15.01 \\
\end{array}$ & $\begin{array}{c}21.95 \\
\pm 15.01 \\
\end{array}$ & $\begin{array}{c}23.05 \\
\pm 21.23 \\
\end{array}$ & $\begin{array}{c}14.15 \\
\pm 21.23 \\
\end{array}$ & $\begin{array}{r}27.35 \\
\pm 21.23 \\
\end{array}$ & $\begin{array}{c}19.95 \\
\pm 21.23 \\
\end{array}$ & $39.509^{b}$ \\
\hline $\begin{array}{l}\text { Overall } \\
\text { mean }\end{array}$ & $97.9^{\mathrm{a}}$ & $88.46^{\mathrm{a}}$ & $105.89^{\mathrm{a}}$ & $30.35^{\mathrm{b}}$ & $29.82^{\mathrm{b}}$ & $21.48^{\mathrm{b}}$ & $31.75^{\mathrm{b}}$ & 57.94 \\
\hline
\end{tabular}

G1= Group that milking for more than 9 months, G2 = Group that milking less than 7 months and G3= Group with no lactation. , Means with different letters in the same column and row are significantly different at 0.05 level of probability.

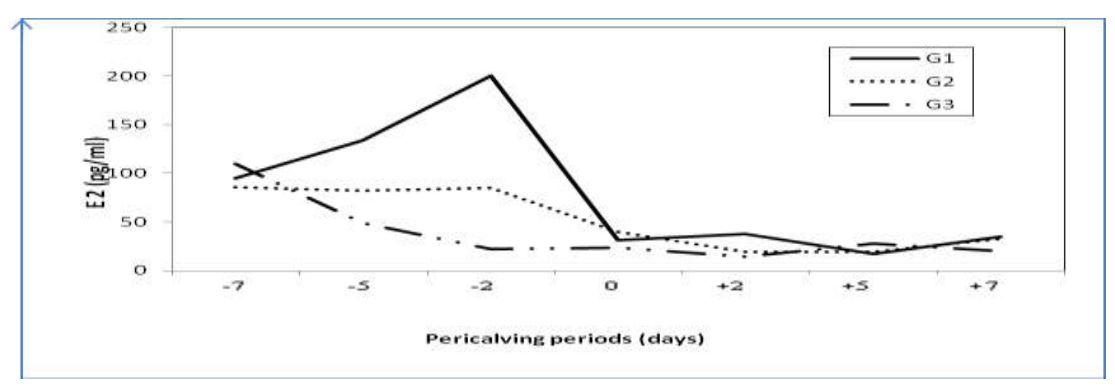

Fig. 1. Average estradiol (E2) concentrations from 7 days before to 7 days after calving in primiparous buffaloes that lactating for more than 9 months (G1), that lactating less than 7 months (G2) and those with no lactation (G3)

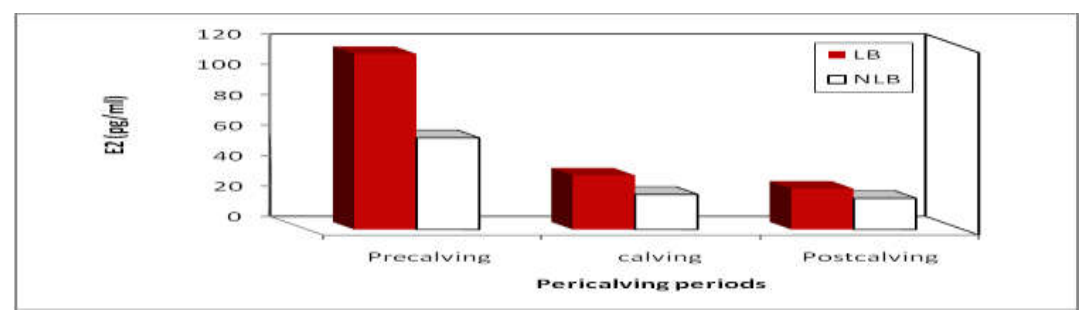

Fig. 2. Average estradiol (E2) concentration during one week before to one week postcalving in lactating (LB) and non- lactating (NLB) primiparous buffaloes 
At calving, G1 and G3 showed the lowest level of P4 which was one -third of that in G2. At that time, level of P4 dropped in G1 to one- fifth of that at 2 days prior calving. However, it was decreased slightly in G2 and almost unchanged in G3.

During the post calving period, the changes in $\mathrm{p} 4$ level were less pronounced than those during pre-calving period. It was slightly fluctuated in G1. Whereas, it was decreased progressively in G2 and increased successively in G3. Therefore, it could be noticed that P4 level at 7 days post calving in G1 and G2 (LB) showed opposite trend to that in G3 (NLB). It was decreased in G1 and G2 and increased in G3.

It is obvious that during the periparturient period, the changes in P4 level agree well with the inhibitory effects of this hormone on lactogensis as observed in G3.The present results are in agreement with those of Short (1958); Stabenfeldt et al. (1970); Smith et al. (1973); and Tucker (1981) who stated that there was a decrease in P4 secretion 1 to 2 days before calving in preparation of the onset of lactation. This activity is inhibited by high concentration of $\mathrm{P} 4$, the primary inhibitor of lactation (Erb, 1976 and Akers, 1985). In addition, P4 competes with glucocorticoids receptors and prevents them from initiating lactation. The parturient rise in glucocorticiods occurred shortly after the fall in P4 (Smith et al., 1973). Furthermore, P4 blocks the ability of PRL to induce synthesis of PRL receptors (Tucker, 1981). As shown in Fig. (4), P4 concentration was higher by $35.8 \%$ in LB (G1 and G2) than that in NLB (G3) during precalving period.

Table 2. Progesterone concentrations $(\mathrm{ng} / \mathrm{ml})$ in nine Egyptian primiparous buffaloes from 7 days before to 7 days after calving (LSM \pm S.E.)

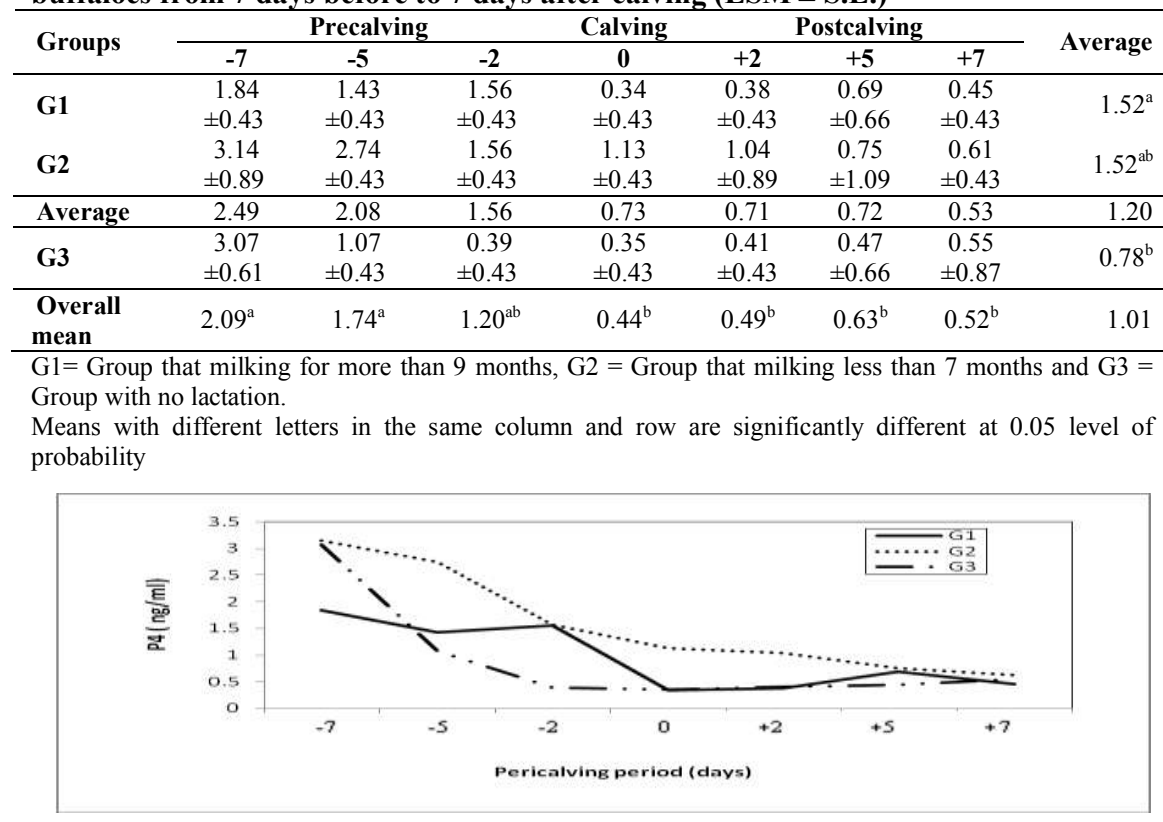

Fig. 3. Average progesterone (P4) concentrations from 7 days before to 7 days after calving in primiparous buffaloes that lactating for more than 9 months (G3) (G1), that lactating less than 7 months (G2) and those with no lactation 


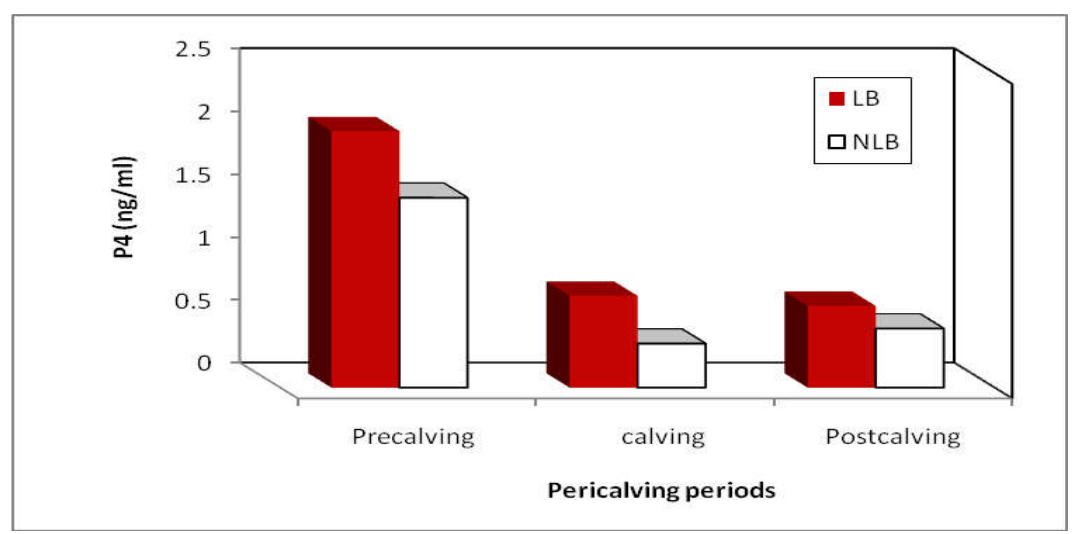

Fig. 4. Average progesterone (P4) concentration during one week before to one week postcalving in lactating (LB) and non- lactating (NLB) primiparous buffaloes

\section{Progesterone-estradiol ratio:}

Comparing P4 and E2 levels in non-lactating (NLB, G3) group with that in the lactating groups (LB, G1 and G2), it was observed that both had higher values in LB than that in NLB during pre-and-post calving periods (Figurs, 2 and 4). The lower levels of P4 and E2 in G3 may indicate hormonal imbalance leading to improper physiological functions related to onset of normal delivery and initiation of milk secretion as well. The rate of decline in $\mathrm{P} 4$ concentration from pre-to-post calving period was $68.3 \%$ in LB vs. $68.2 \%$ in NLB. While, that of decline in E2 was $76.8 \%$ in LB vs. $66.0 \%$ in NLB. In lactating groups, P4/E2 ratios were 17.75 and 24.22 in pre and post calving, respectively, while, those in NLB were 25.05 and $23.44 \%$, respectively (Table 3). This finding indicates that prepartum level of P4 was abnormally greater or that of E2 was abnormally lower in NLB so that greater P4/E2 ratio $(25.05 \%)$ attained which is not in favor of milk secretory mechanism.

Table 3. Average of estradiol (E2), progesterone (P4) and ratio of P4/E2 in lactating groups (G1 and G2) and non-lactating group (G3) during peripartum period

\begin{tabular}{|c|c|c|c|c|c|c|}
\hline \multirow[t]{2}{*}{ Hormone } & \multicolumn{2}{|c|}{ Lactating (LB) } & \multicolumn{2}{|c|}{ Non-lactating (NLB) } & \multicolumn{2}{|c|}{$\begin{array}{l}\text { Rate of } \\
\text { decline }\end{array}$} \\
\hline & Prepatum & Postpartum & Prepatum & Postpartum & LB & NLB \\
\hline E2 & 115.49 & 26.84 & 60.29 & 20.48 & 88.65 & 39.81 \\
\hline P4 & 2.04 & 0.65 & 1.51 & 0.47 & 1.39 & 1.04 \\
\hline $\mathrm{P} 4 / \mathrm{E} 2$ & 17.66 & 24.22 & 25.05 & 22.95 & -6.55 & 2.1 \\
\hline
\end{tabular}

Generally, the three experimental groups exhibited a downward trend of P4 concentration during prepartum period until day of calving. However, concentrations of P4 were relatively higher in G2 than that in G1 and G3 during prepartum period and day of calving. The overall mean of $\mathrm{P} 4$ concentration during postpartum period was significantly less than that during the prepartum period for all studied groups and it was relatively greater in $\mathrm{G} 2$ than other groups. 
Lactation potency:

Milk production is largely dependent on the shape of lactation curve. The key element that describes the pattern of milk is peak yield, which represent the maximum output during the lactation and its persistency. Bussi and Sala (1993) stated that lactation period in buffalo is less than cattle (250 vs. 300 days) and the total amount of milk production in buffalo is less than cattle (2000 kg vs. $7.200 \mathrm{~kg})$ and as mentioned by Meikle et al. (2004), the primiparouse cattle are producing milk less than multiparous cattle and they attributed that to mammary gland which is more metabolically active in multiparous than primiparous cow and the DNA content of mammary secretory cells is lower in primiparous than multiparous. In the present study, as shown in Table (4) the average of lactation period length in G1 (285 days) was longer than that in G2 (156 days) by $82.7 \%$. The average of the total milk yield in the two groups (G1 and G2) is lower than that recorded by Aziz and Badran (1993) who found that the amount of total milk yield in Egyptian buffaloes is $1669 \mathrm{~kg}$. In addition, the average of daily milk yield (DMY) of lactating primiparous buffalo in the present study was higher than that recorded by Barbosa et al. (2007) and AbouZiena et al. (2009) who recorded that the average DMY in buffaloes was 3.51 and $3.97 \mathrm{~kg}$, respectively. The lactation performance of these primiparous buffaloes as presented in Table (4) could be attributed to the levels of E2 especially before calving by 2 days as discussed previously which was higher in G1 than G2 by $110.3 \%$ than that in G3, this may help the mammary gland of these buffalo heifers to develop more during lactation through the effect of E2 on releasing prolactin. In addition, the heifers of G2 were slightly hard in milking compared with the heifers in G1. This may make this group loosing the role of milking in stimulating prolactin release from pituitary gland, as reported by Akers (1985) who stated that milking or even teat stimulation causes release of prolactin.

Table 4. Lactation period (LP), total milk yield (TMY) and daily milk yield (DMY) in primiparous buffaloes that milking more than 9 months (G1) and those milking less than 7 months (G2)

\begin{tabular}{|c|c|c|c|c|c|}
\hline \multirow[b]{2}{*}{ Group } & \multirow[b]{2}{*}{ Buffalo } & \multirow[t]{2}{*}{$\begin{array}{c}\text { LP } \\
\text { (day) }\end{array}$} & \multirow[t]{2}{*}{$\begin{array}{l}\text { TMY } \\
\text { (kg) }\end{array}$} & \multicolumn{2}{|c|}{$\begin{array}{c}\text { DMY } \\
\text { (kg) }\end{array}$} \\
\hline & & & & Mean \pm SE & Range \\
\hline \multirow{3}{*}{ G1 } & 1 & 286 & 1866 & $7.0 \pm 0.6$ & $2-12$ \\
\hline & 2 & 290 & 1905 & $6.2 \pm 0.5$ & $2-10$ \\
\hline & 3 & 279 & 959 & $4.8 \pm 0.4$ & 1- 8 \\
\hline \multicolumn{2}{|c|}{ Average } & 285 & 1576 & 6.01 & $1.6-10$ \\
\hline \multirow{3}{*}{ G2 } & 4 & 84 & 782 & $8.3 \pm 0.7$ & $6-11$ \\
\hline & 5 & 199 & 1541 & $7.3 \pm 0.7$ & $2-10$ \\
\hline & 6 & 185 & 654 & $3.7 \pm 0.3$ & $2-7$ \\
\hline \multicolumn{2}{|c|}{ Average } & 156 & 992 & 6.44 & $3.3-9.3$ \\
\hline
\end{tabular}

\section{CONCLUSION}

Apart from the involvement in reproductive functions, changes in each of E2 and P4 concentrations in this study are synchronized for mammary gland development and prospective potency of lactation. It is well known that E2 alone stimulates duct proliferation but normal lobule-alveolar development requires synergistic effects of E2 and P4. This action is secured by drop of P4 level concomitant with high level of 
E2 as found in G1 alongside in comparison with G2. It is clear that G3 which had a very low concentration of E2 and a considerable high concentration of P4 failed to produce milk. This synergistic action is fulfilled by: a) increased permeability of cellular membrane, b) accumulation of fluid in extracellular spaces, increased vascularity and, presumably, increased blood flow rate and c) stimulation of RNAdirected synthesis of cellular proteins in the secretory cells. The present results revealed that additional researches will be necessary to clarify the interaction of estradiol and progesterone prior to parturition. Also, monitoring of the hypophyseal, adrenal, ovarian and placental hormones simultaneously will be required to complete understanding of parturition and lactogenesis in primiparous buffalo under good managerial conditions and on large numbers.

\section{REFERENCES}

Abou-Ziena A. H., S. G. Hassan and A. M. Hamam, 2009. Trials for elevating adverse effect of heat stress in buffaloes with emphasis on metabolic status and fertility. J. Global Vet., 3(1): 51-62.

Afzal M., M. Anwar and M. A. Mirza, 2007. Some factors affecting milk yield and lactation length in Nili Ravi Buffaloes. Pakistan Vet. J., 27(3): 113 - 117.

Akers R.M. 1985. Lactogenic hormones: binding sites, mammary growth, secretory cell differentiation and milk biosynthesis in ruminants. J. Dairy Sci., 68:501 519.

Akers R.M., 2006. Major advances associated with hormones and growth factors regulation of mammary growth and lactation in dairy cows. J. Dairy Sci., 89: $1222-1234$.

Aziz M. and A. Badran, 1993. Effect of age at first calving on milk yield and lactation length in Egyptian buffalo. Proc. Int. Symp., 9-12 November, 1992, Cairo, Egypt, EAAP Publication, No.: 62: 246-249.

Barbosa S.B.P., R.G.A. Pereira, K.R. Santoro, A.M.V. Batista and A.C. Ribeiro Neto, 2007a. Milk yield of cross - bred buffalo under two production systems in the Amazonian region of Brazil. Ital. J. Anim. Sci., 6 (Suppl. 2): 1071-1074.

Bussi B. and L. Sala, 1993. Buffalo rearing in non- traditional zone of Italy: The Lombardia region preliminary note. Proc. Int. Symp., 9-12 November, 1992, Cairo, Egypt, EAAP Publication, No.: 62: 250-257.

Chew B.P., H.F. Keller, R. E. Erb and P. V. Malven, 1977. Periparturient concentrations of prolactin, progesterone and the estrogens in blood plasma of cows retaining and not retaining fetal membranes. J. Anim. Sci., 44:1055-1060.

Convey E.M., 1974. Serum hormone concentrations in ruminants during mammary growth, lactogenesis and lactation: A review. J. Dairy Sci., 57: 905-917.

Cowie A. J., I. A. Forsyth and T. C. Hart, 1980. Hormonal control of lactation.. Endocrinol., 15: 22-31.

Divakar J., D. Ambrose and G.V. Emmanuel, 2008. Precocious mammary development in an 8-month-old Holstein heifer. Can. Vet. J., 49:803-805.

Delouis C., L. Djiane, M. Houdebine and M. Terqui, 1980. Relationship between hormones and mammary gland function. J. Dairy Sci., 63:1492-1513.

Duncan D.E., 1955. Multiple range and Multiple F test. Biometrics, 11: 1.

Elias J.J., 1980. Hormonal Proteins and Peptides. Vol. VIII., (Ed.Li, C.H.), Academic Press, New York, USA, 641pp. 
Erb R.E., 1976. Hormonal control of mammogenesis and onset of lactation in cows A review. J. Dairy Sci., 60:155 - 169.

Erb R.E., F.M. D'Amico, B. P. Chew and C.N. Zamet, 1981. Variables associated with peripartum traits in dairy cows. VIII. Hormonal profiles associated with dystocia. J. Anim. Sci., 52: 346-358.

Henrichs D. M., J.F. Dickey and W.E. Johnston, 1972. Plasma estrogen and progesterone levels after mating, and during late pregnancy and postpartum in cows. J. Endocrinol., 90: 1336-1342.

Ilieva Y. and T. Peeva, 2007. Productive life in buffalo cows and effects of some factors on it. Ital. J. Anim. Sci., 6 (Suppl. 2), 375 - 377.

Kaker M.L., R.D. Murray and H. Dabson, 1984. Plasma hormone changes in cows during induced or spontaneous calving and in early postpartum period. Vet. Rec., 115: 378-382.

Keller H.F., B.P. Chew and R.E. Erb, 1977. Mammary transfer of hormones and constituents into secretions when cows were milked or secretions were sampled prepartum. J. Dairy Sci., 60: 546 - 556.

Meikle M., Y. Kulcsar, H. Chilliard, C. Febel, D. Delavaud and P. Chilibroste, 2004. Effects of parity and body condition at parturition on endocrine and reproductive parameters of the cow. J. Reprod., 127: 727-737.

Neville M.C., J. Marton and S. Umemora, 2001. Lactogenesis: the transition from pregnancy to lactation. Pediatr. Clin. North Am., 48: 35 - 52.

Neville M.C., T. B. McFadden and I. Forsyth, 2002. Hormonal regulation of mammary differentiation and milk secretion. J. Mammary Gland Biol. Neopl., 7 (1):49-66.

Omar E. A., R. M. Khattab and K. A. Mourad, 1994. Hormonal induction of lactation in parturant non-lactating Egyptian buffaloes. J. Agric. Sci. Mansoura Univ., 19 (1): 173-180.

SAS, 1999. SAS users guide. Statistical analysis system Institute, Inc., Cary, NC, USA.

Short R. V., 1958. Progesterone in blood. II. Progesterone in the peripheral blood of pregnant cows. J. Endocrinol., 16: 426-432.

Smith M. G., L. A. Edgerton, H. D. Hafs and E. M. Convey, 1973. Bovine serum estrogens, progestins and glucocoriticoids during pregnancy, parturition and early lactation. J. Anim. Sci., 36: 391- 396.

Stabenfeldt G.H., B.E. Osburn and L.L. Ewing, 1970. Peripheral plasma progesterone levels in the cow during pregnancy and parturition. Am. J. Physiol., 218: 571-580.

Topper Y.J. and C.S. Freeman, 1980. Multiple hormone interactions in the developmental biology of the mammary gland. Physiol. Rev., 60:1049-1055.

Tucker H.A., 1979. Endocrinology of lactation. Semin. Perinatol., 3:199-210.

Tucker H.A., 1981 Physiological control of mammary growth, lactogenesis, and lactation. J. Dairy Sci., 64:1403 - 1421.

Tucker H.A., 2000. Hormones, mammary growth and lactation: a 41- year perspective. J. Dairy Sci., 83: 874-884.

Turner C.D. and J.T. Bagnara, 1971. The effect of estrogens. In: "General Endocrinology", $5^{\text {th }}$ (ed). Saunders W. B. CO., Philadelphia, USA, pp, 511-515. 
تركيز هرمونى الإستراديول والبروجستيرون حول الولادة في دم العجلات الجاموسى كمؤشر علي القدرة المتوقعة لنشاط الغدة اللبنية

جمـال عاشور حسن', هدى زكي حسن', سماح محمد عبد الرحمن', أحمد محمد حسنين", محمد

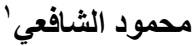

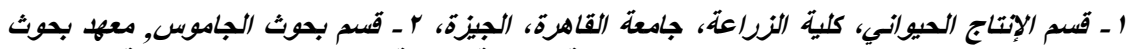

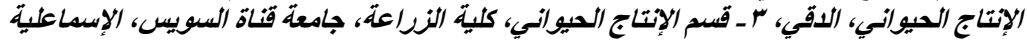

تم تقدير مستويات هرموني الإستراديول و البروجستيرون في دم العجلات الجاموسى خلال فترة

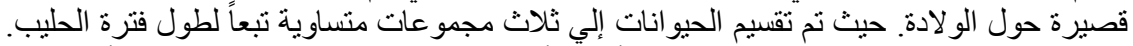

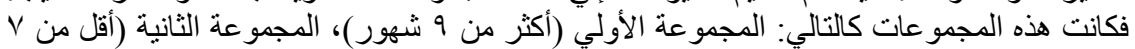
شهور ) أما المجموعة الثجات عالثة (الغير حلابة).

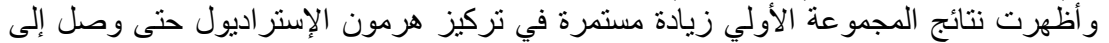

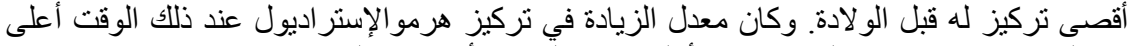

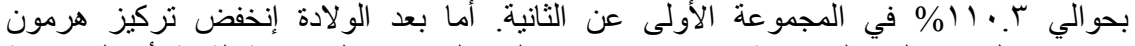

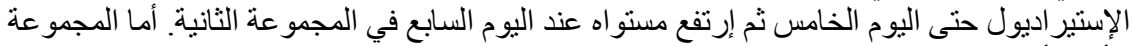

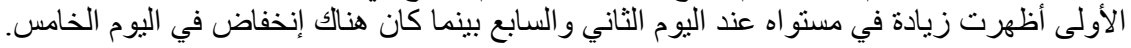

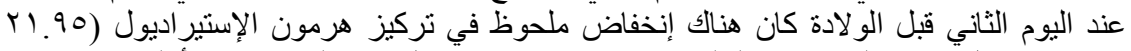

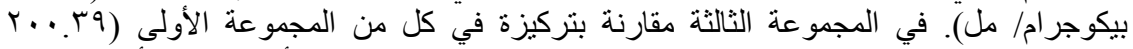

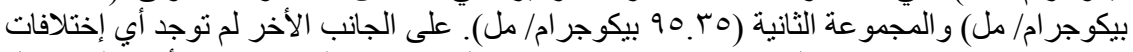

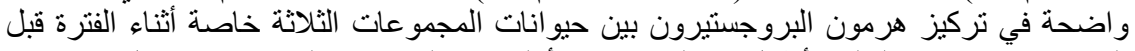

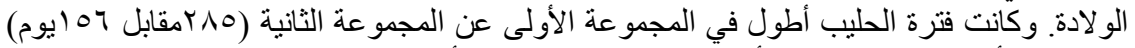

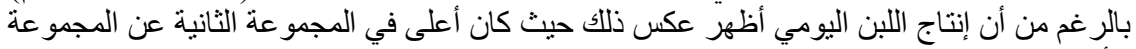

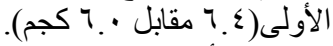
ويمكن أن نستنتج من هذه الدراسة أن التغير في تركيز ات هرمون الإن الإستر اديول حول الو لادة يعتبر

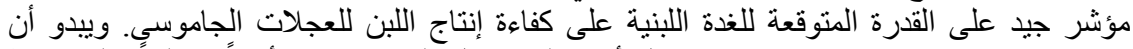

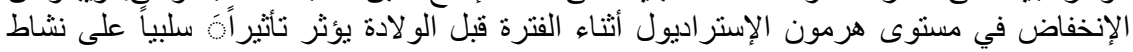

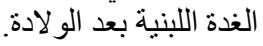

